\title{
Circumpolar dispersal by rafting in two subantarctic kelp-dwelling crustaceans
}

\author{
R. Nikula*, C. I. Fraser, H. G. Spencer, J. M. Waters \\ Allan Wilson Centre for Molecular Ecology and Evolution, Department of Zoology, University of Otago, PO Box 56, \\ Dunedin 9054, New Zealand
}

\begin{abstract}
Long-distance oceanic rafting is frequently invoked as an explanation for broad geographic distributions of sedentary marine taxa, but evidence for this ecological process remains elusive. We explored empirically the potential of rafting as a dispersal mechanism by comparing circumpolar mtDNA variability in 3 codistributed subantarctic taxa: 2 direct-developing epifaunal crustacean species (Limnoria stephenseni, Parawaldeckia kidderi) and their macroalgal host (Durvillaea antarctica). A previous study of $D$. antarctica suggests that its subantarctic populations were established only postglacially, and we predict that the epifaunal invertebrates associated with it experienced a parallel island-colonization episode, facilitated by kelp-rafting. We generated and analysed mtDNA sequence data (cytochrome oxidase subunit I [COI] gene, >900 base pairs) from 89 L. stephenseni and 62 P. kidderi specimens and reanalysed previously published comparable data for D. antarctica. Both epifaunal species exhibited wide-scale circumpolar distributions of a single haplotype. Little sequence diversity was found within island samples, with the exception of $P$. kidderi in the Falkland Islands. The phylogeographic diversity and structuring of the invertebrates was very similar to that of their kelp host and consistent with a scenario of subantarctic recolonization and population expansion. The dependence of these otherwise non-dispersive crustaceans on macroalgal holdfasts for food and habitat, as well as the great abundance of $D$. antarctica adrift in the Antarctic Circumpolar Current (ACC), support rafting as their most plausible recolonization mechanism. We suggest that macroalgal rafting may explain similarities in the species composition of intertidal marine communities across the subantarctic.
\end{abstract}

KEY WORDS: Rafting · Long-distance dispersal • Marine biogeography · Phylogeography · Macroalga $\cdot$ mtDNA $\cdot$ Peracarida $\cdot$ Durvillaea antarctica

\section{INTRODUCTION}

The enormous geographic ranges of some species that would otherwise be expected to have low dispersal abilities have intrigued biologists for well over a century (see Darwin 1845, Johannesson 1988). The acceptance of the plate tectonic theory in the late 1960s inspired largely vicariant explanations of such broad distributions (e.g. Garbary 1987, Chin et al. 1991), with many historical biogeographers tending towards the view that species distributions are driven more by long-term geological processes than by dispersal events (Nelson \& Platnick 1981, Humphries \& Parenti 1999, Ebach \& Tangney 2007). The increasing use of molecular data in biogeographical research has, however, demonstrated that general (multitaxon) biogeographical patterns can be generated via long-distance oceanic dispersal events, if the mechanism allowing for dispersal operates steadily over long periods (see review by Sanmartín et al. 2007).

In light of new molecular phylogenetic evidence for passive oceanic rafting as a mechanism for historic long-distance dispersal (Waters \& Roy 2004, de Queiroz 2005, Donald et al. 2005, Gordillo 2006, Waters 2008), we predict that the potential of rafting macroalgae to shape composition of island biotas may be substantial. By examining patterns of intraspecific genetic variation among communities that have a biological propensity 
for passive dispersal, and no means for active dispersal, it may be possible to elucidate the ecological and evolutionary importance of long-distance rafting (Edgar 1987, Helmuth et al. 1994, Thiel \& Haye 2006).

Ecological (Ingolfsson 1995, Edgar \& Burton 2000, Macaya et al. 2005) and genetic (Coyer et al. 2001, Muhlin et al. 2008, Muhlin \& Brawley 2009) studies of buoyant macroalgae suggest that macroalgal rafting may be an important process in the generation and distribution of biodiversity in marine systems. Long-distance dispersal of intertidal organisms by rafting on detached macroalgae may be especially significant in the subantarctic marine regions, where a series of oceanic and continental islands separated by hundreds to thousands of $\mathrm{km}$ of open ocean lie amid the powerful Antarctic Circumpolar Current (ACC; Fig. 1). At speeds measured for the ACC (20 to $40 \mathrm{~cm} \mathrm{~s}^{-1}$; Hofmann 1985), an $8000 \mathrm{~km}$ rafting journey from Campbell Island to Falkland Islands, for example, would take ca. 1 yr.

Durvillaea antarctica (Chamisso) Hariot (Phaeophyceae) or southern bull kelp ('bull kelp' for brevity) presents an ideal system for studies of rafting biology. Exposed subantarctic coastlines are characterised by dense beds of this robust and highly buoyant kelp.

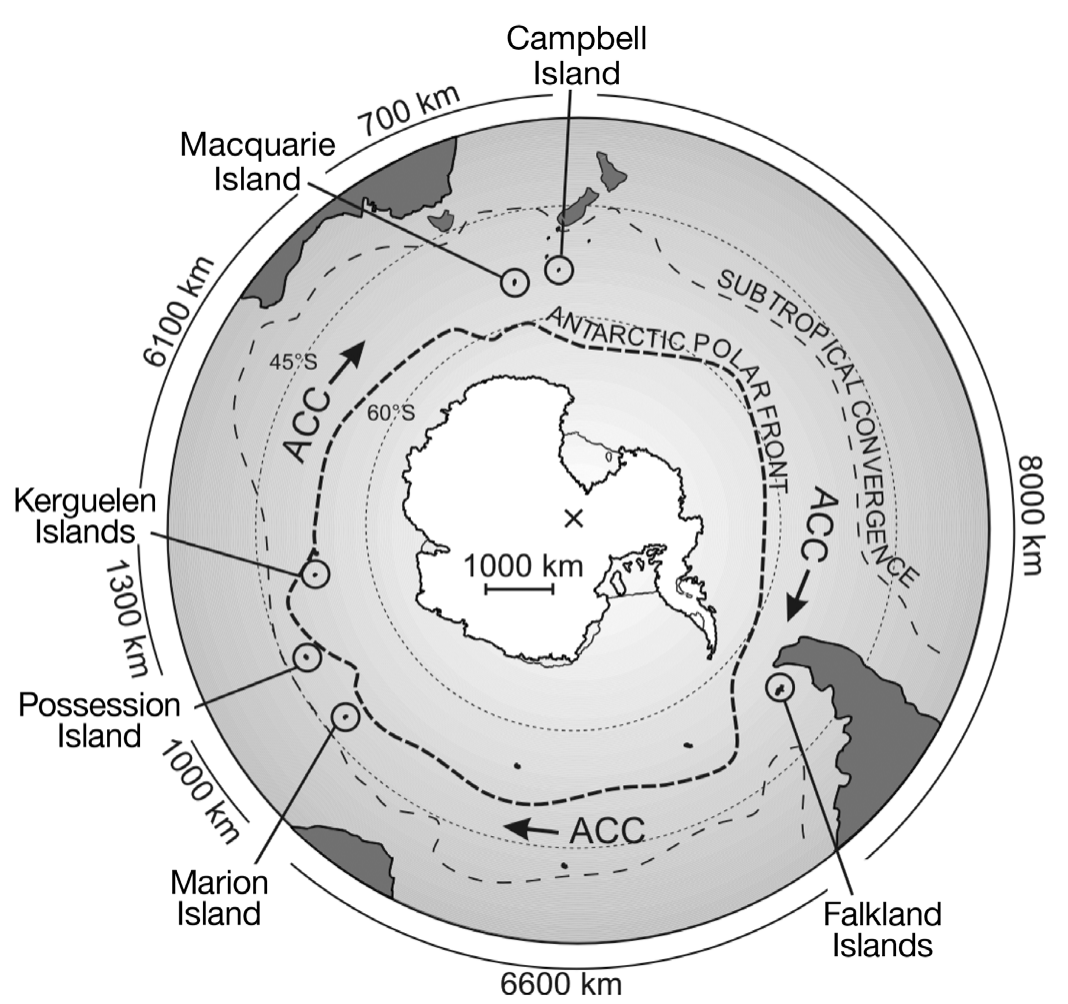

Fig. 1. Polar-centric view of the subantarctic region showing the 6 islands or island groups sampled for southern bull kelp epifauna. The clockwise Antarctic Circumpolar Current (ACC) operates at and between the Subtropical Convergence and the Antarctic Polar Front. Approximate longitudinal distances between sampling locations are indicated
Detached $D$. antarctica have been inferred to float for at least $5000 \mathrm{~km}$ in the ACC (Dartnall 1974). The ACC has been estimated to have 20 million $D$. antarctica plants adrift with intact holdfasts at any one time (Smith 2002). Detached D. antarctica plants cannot reattach, but likely continue to grow and remain reproductively viable while afloat, as observed for other buoyant phaeophycean taxa (e.g. Macrocystis, Macaya et al. 2005). The large, domed holdfasts of $D$. antarctica (Fig. 2a) support high biodiversity when attached to the rocky substrate (Morton \& Miller 1968, Smith \& Simpson 2002), with many crustacean, molluscan, annelid and echinoderm species exploiting them as a habitat and food source (Edgar \& Burton 2000). Modification of a solid holdfast into a habitat for invertebrates often begins with the creation of intricate chambers by Limnoria isopods (Fig. 2a). Members of several other widespread crustacean (e.g. Parawaldeckia, Hyale; Smith \& Simpson 2002) and molluscan (e.g. Kerguelenella, Margarella, Onchidella; Morton \& Miller 1968) genera may then enter and hollow out the holdfast further, reducing the extent of attachment to the rocky substrate, and presumably increasing the probability of holdfast detachment and subsequent drifting.

Although dispersal via rafting is by no means a new idea (e.g. Wheeler 1916, Heatwole \& Levins 1972, Highsmith 1985), molecular genetic markers have not been previously used to assess connectivity in macroalgal epifauna on a circumpolar scale. We here examine phylogeographic structuring across the subantarctic in 2 widespread peracarid crustacean taxa that dwell within bull kelp holdfasts: Limnoria stephenseni Menzies, 1957 (Isopoda: Limnoriidae), and Parawaldeckia kidderi (Smith, 1876) (Amphipoda: Lysianassidae) (Fig. 2b,c). We compare and contrast their mtDNA phylogeography to previously published data (Fraser et al. 2009) on their macroalgal host, Durvillaea antarctica.

The 2 invertebrate species analysed here are abundant and widespread members of the subantarctic epifaunal community of Durvillaea antarctica (Edgar 1987, Smith \& Simpson 2002). As they are sedentary and produce directdeveloping offspring, rafting is presumably their primary means of dispersing to and between remote oceanic islands. Indeed, individuals of these taxa are unlikely to move more than a few metres unassisted (Eltringham \& Hockley 1961, 

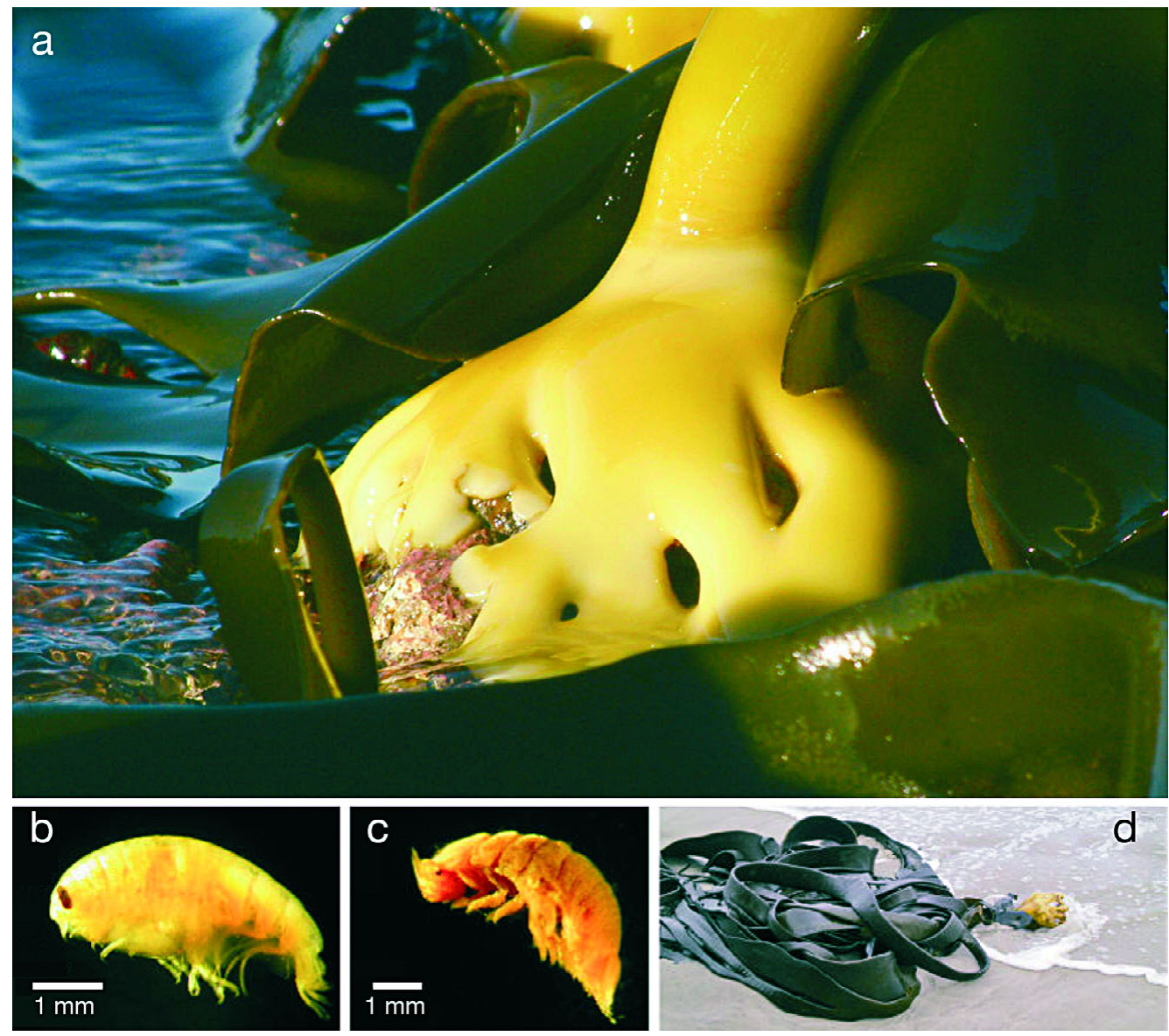

Fig. 2. Durvillaea antarctica, Parawaldeckia kidderi and Limnoria stephenseni. (a) Southern bull kelp growing in the subantarctic rocky intertidal, with holdfast showing evidence of invertebrate excavation and colonization. Crustacean invertebrates (b) P. kidderi and (c) L. stephenseni that inhabit southern bull kelp holdfasts. (d) Southern bull kelp cast ashore on a sandy beach
Lowry \& Stoddart 1983). Rafting, on the other hand, provides potential for long-distance dispersal, and both genera have been observed in the holdfasts of beach-cast specimens of $D$. antarctica in New Zealand (J. M. W. pers. obs.). Both of these epifaunal species can also exploit holdfasts of other large buoyant seaweeds such as Macrocystis pyrifera (Edgar 1987) and Lessonia spp. (Cookson 1991). While the other presumptive macroalgal host species are similarly broadly distributed across the subantarctic (Dhargalkar \& Verlecar 2009), D. antarctica is likely to play a key role in rafting as its rafts are the most abundant and longestlived at sea (Smith 2002). Unlike some of its congeners, Limnoria stephenseni has never been found on other buoyant substrates (e.g. wood).

A recent global phylogeographic survey of Durvillaea antarctica inferred that most subantarctic populations of the species were re-established after the Last Glacial Maximum, most plausibly following elimination by sea ice that scoured the intertidal zone (Fraser et al. 2009). Obligate epifauna of intertidal macroalgae are predicted to have experienced a similar demise and to have relied on rafting on macroalgae in their recolonization of the subantarctic islands. These historical hypotheses would be supported by obligate kelp-holdfast dwelling invertebrates (Limnoria stephenseni, Parawaldeckia kidderi) showing (1) little genetic variation across the farflung subantarctic intertidal habitats, and (2) phylogeographic structuring across the subantarctic similar to that of their macroalgal host (D. antarctica).

\section{MATERIALS AND METHODS}

Sample collection. Holdfast epifaunal samples were collected from bull kelp beds on 6 oceanic islands located in 'subantarctic' waters south of $46^{\circ} \mathrm{S}$ in the South Atlantic, South Indian and South Pacific Oceans: Falkland Islands, Marion Island (Prince Edward Island group), Possession Island (in the Crozet Archipelago), and Kerguelen, Macquarie and Campbell Islands (Fig. 1, Tables 1 \& 2). Animals were collected from whole holdfasts that were detached from their rocky substrate during low tide using a hatchet. The numbers of Parawaldeckia kidderi in a typical holdfast were generally substantially larger than numbers of 
Preparation of data. We extracted total genomic DNA from leg or pleotelson muscle tissue of the invertebrates using a standard Chelex method (Walsh et al. 1991). A fragment of the mitochondrial gene coding for cytochrome oxidase subunit I (COI) was amplified using the universal invertebrate primers LCO1490 (5'GGT CAA CAA ATC ATA AGA TAT TGG-3') (Folmer et al. 1994) and H7005mod1 (5'-ART GNG CNA CNA CRT ART ANG TRT CRT G-3') (Donald et al. 2005), under the following conditions in an Eppendorf Mastercycler: initial denaturation phase of $2 \mathrm{~min}$ at $95^{\circ} \mathrm{C}$; 40 cycles of $50 \mathrm{~s}$ at $95^{\circ} \mathrm{C}, 1 \mathrm{~min} 30 \mathrm{~s}$ at $48^{\circ} \mathrm{C}, 1 \mathrm{~min} 30 \mathrm{~s}$ at $72^{\circ} \mathrm{C}$; final extension step of $10 \mathrm{~min}$ at $72^{\circ} \mathrm{C}$. PCR products were purified using the Invitrogen Purelink PCR purification kit, and sequenced by the Allan Wilson Centre Genome Service. The primer LCO1490 was used for sequencing COI of Parawaldeckia kidderi. Sequencing of Limnoria stephenseni COI was done with an internal forward primer (5'-TCATTCGGC TTG AGC TAG GGC A-3') that was designed based on preliminary sequences obtained using the universal primers (above). Numbers of sampled individuals and holdfasts per island and species are listed in Table 2. The sequences were deposited in GenBank under accession numbers FJ608831-FJ608981. Details of sampling localities and GenBank accessions per species per locality are presented in Table 1.

Data analysis. Sequence chromatograms were inspected, edited, aligned and the amino acid translation of the sequences checked using Sequencher 4.8 software (GeneCodes). The lengths of the homologous sequence fragments, qualified for final analysis by having complete data across all studied individuals, were 912 and 980 nucleotide base pairs in Limnoria stephenseni and Parawaldeckia kidderi, respectively. Intraspecific genealogical relationships of the COI haplotypes were estimated with the statistical parsimony method, implemented in program TCS 1.21 (Clement et al. 2000). Nucleotide and haplotype diversity indices were calculated with DnaSP 4.50 software (Rozas et al. 2003). Two-level hierarchical analysis of molecular variance, as implemented in Arlequin (Excoffier et al. 2005), was performed for the total data set of each species in order to break the total intraspecific variation into between-island and within-island components. Arlequin was also employed in calculation of Fu's $F_{\mathrm{S}}$ neutrality statistic (Fu 1997) and in testing its statistical significance by generating 1000 random samples under the assumption of selective neutrality. In addition to selection, a historical population size contraction and subsequent expansion is also predicted to result in an excess of singleton mutations in a population relative to a historically constant-size population; both are indicated by negative values of Fu's $F_{\mathrm{S}}$ (Ramos-Onsins \& Rozas 2002). Differentiation between island samples was quantified by calculating with Arlequin population pairwise fixation index $\left(F_{\mathrm{ST}}\right)$ values based on within-population and between-population nucleotide differences. Significance of the $F_{\mathrm{ST}}$ values was tested against 1023 random permutations of the data. Comparable statistics for subantarctic Durvillaea antarctica - details not reported by Fraser et al. (2009) — were calculated for the subantarctic COI clade of this species ( $\mathrm{N}=174$; GenBank acc. nos. FJ550090-FJ550092, FJ550101-FJ550104, FJ550107). This kelp data set included samples from 5 more subantarctic islands than our epifaunal data sets (Antipodes, Auckland, Snares and Gough Islands, and South Georgia; see Fraser et al. 2009), owing to the absence of the invertebrate species in holdfast samples or lack of holdfast samples from these islands.

\section{RESULTS}

\section{Diversity and distribution of mtDNA COI haplotypes}

We detected a single haplotype with a circumpolar distribution in both epifaunal crustacean species (Fig. 3a,b). In each case, the circumpolar haplotype also occupied a central position in the inferred statistical parsimony network and was the most common haplotype, carried by $38 \%$ of Parawaldeckia kidderi and $67 \%$ of the Limnoria stephenseni specimens. In both species, within-island polymorphism consisted mostly of low-frequency haplotypes inferred to have descended directly from the ancestral circumpolar haplotypes, producing a star-like network. All but one of the rare haplotypes were restricted to single islands, and they were seldom more than 2 mutational steps divergent from the common circumpolar haplotype. Overall diversity was higher in P. kidderi than in L. stephenseni, as shown by the haplotype networks (Fig. 3a,b) and molecular diversity indices (Table 3). Haplotypic diversity was higher in the epifaunal invertebrate samples than previously observed in their host Durvillaea antarctica.

The phylogeographic patterns of the 2 invertebrate species differed substantially in the case of the Falkland Islands, where Limnoria stephenseni had 3 rare haplotypes along with the circumpolar haplotype, but Parawaldeckia kidderi samples completely lacked the circumpolar haplotype. Instead, the sampled Falkland $P$. kidderi haplotypes were between 2 and 13 mutational steps divergent from the circumpolar haplotype, and a total of 4 distinct haplotype lineages were present in the sample. Of these lineages, 2 were closely related to the circumpolar haplotype and to the rare haplotypes found on the other islands, whereas the other 2 were $\sim 1.3 \%$ different from it and from each 


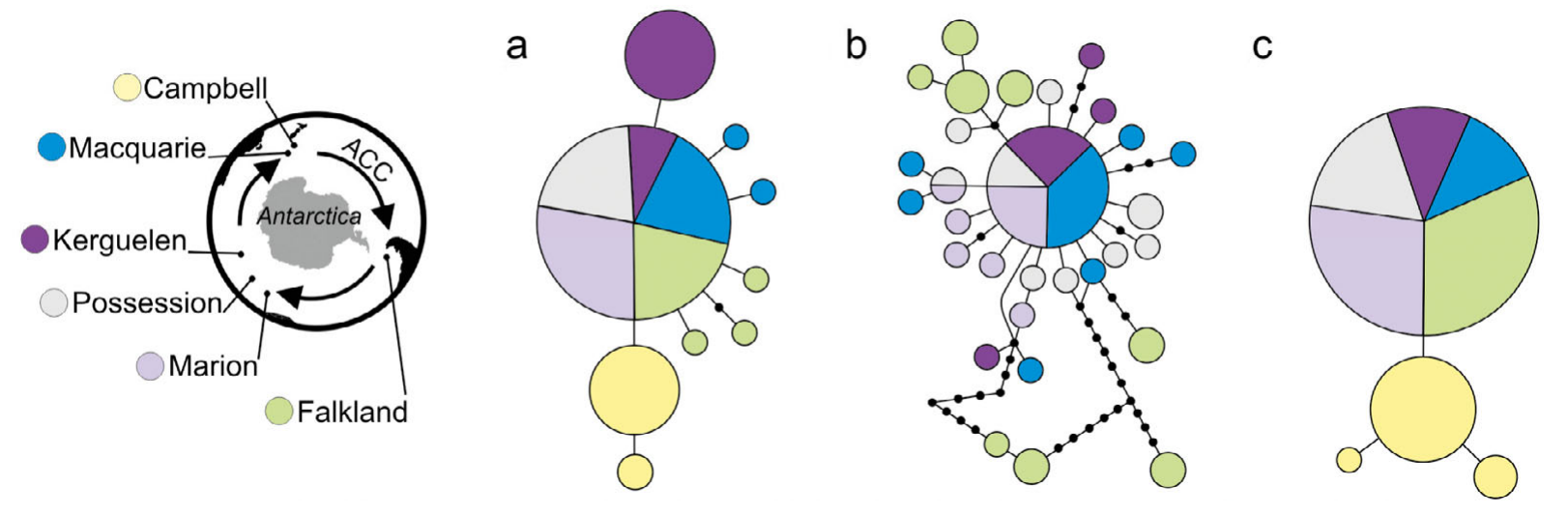

Fig. 3. Limnoria stephenseni, Parawaldeckia kidderi and Durvillaea antarctica. Unrooted statistical parsimony networks of mitochondrial cytochrome oxidase subunit I (COI) haplotypes sampled in subantarctic island populations of southern bull kelp crustacean epifauna: (a) isopod L. stephenseni, (b) amphipod P. kidderi. (c) A network for their hosts, the brown macroalga, D. antarctica, was redrawn after Fraser et al. (2009, their Fig. 2) to encompass the same island populations. Each circle/pie represents a distinct mitochondrial haplotype; a line connecting 2 haplotypes corresponds to one inferred mutational step separating them. Small black circles: hypothetical, unsampled haplotypes. Area and colours: sampling frequency and locations of each haplotype, respectively; area of the smallest colored circle corresponds to one copy of a haplotype. Left: island colour codes used in the halotype networks. ACC: Antarctic Circumpolar Current

Table 3. Limnoria stephenseni, Parawaldeckia kidderi and Durvillaea antarctica. Circumpolar mtDNA cytochrome oxidase subunit I (COI) sequence variability in L. stephenseni and P. kidderi, and in their macroalga host D. antarctica (calculated from publ. data by Fraser et al. 2009; GenBank acc. FJ550090-FJ550092; FJ550101-FJ550104; FJ550107). Sample size (N), number of detected haplotypes $\left(N_{\mathrm{h}}\right)$, nucleotide diversity $(\pi)$, haplotype diversity $(H)$, Fu's $F_{\mathrm{S}}$ statistic with probability $(p)$ that a simulated $(\operatorname{sim}$.) value $\leq$ observed (obs.) value, and partition of the variation to among- and within- island components according to analysis of molecular variance (AMOVA) are shown as calculated from all samples in the subantarctic per species and from 2 geographical partitions of the $P$. kidderi data set

\begin{tabular}{|lccccccc|}
\hline Taxon/partition & $N$ & $N_{\mathrm{h}}$ & $\pi$ & $H$ & $F_{\mathrm{S}}\left(p\left[\operatorname{sim} . F_{\mathrm{S}} \leq \mathrm{obs} . F_{\mathrm{S}}\right]\right)$ & Among (\%) & Within $(\%)$ \\
\hline Limnoria stephenseni & 89 & 9 & 0.0007 & 0.52 & $-5.4(\mathrm{p}=0.006)$ & 65 & 35 \\
Parawaldeckia kidderi & 62 & 30 & 0.0039 & 0.85 & $-20.2(\mathrm{p}=0.000)$ & 15 & 85 \\
Falkland Is. & 15 & 8 & 0.0092 & 0.92 & $1.5(\mathrm{p}=0.790)$ & - & 0 \\
Excluding Falkland Is. & 47 & 22 & 0.0015 & 0.74 & $-24.3(\mathrm{p}=0.000)$ & $-4.2(\mathrm{p}=0.035)$ & 80 \\
Durvillaea antarctica & 174 & 8 & 0.0009 & 0.30 & -4.200 & 20 \\
\hline
\end{tabular}

other (uncorrected COI divergence). Notably, both of these divergent $P$. kidderi lineages were found in samples collected from the ACC-exposed Sea Lion Island, whereas the lineages closer to non-Falkland haplotypes dominated the more sheltered locations (Surf Beach, Cape Pembroke). In contrast to the broad circumpolar haplotype sharing, L. stephenseni specimens from Campbell Island did not share haplotypes with other subantarctic island samples, but instead, had a unique haplotype group that was one mutational step away from the circumpolar haplotype; the same feature was found in Durvillaea antarctica (Fig. 3c).

\section{Differentiation between islands and indicators of population expansion}

Fixation index values and their tests of significance (Table 4) reveal the Falkland Islands' Parawaldeckia kidderi sample as significantly different from all other island samples; no statistically significant differentiation was found among any other island samples in $P$. kidderi. In the Limnoria stephenseni data set, the Kerguelen and Campbell Islands' samples were significantly different from those of all other islands and from one another, whereas for Durvillaea antarctica, only Campbell Island populations were significantly different from all others. No significant differentiation was inferred for any of the 3 species among samples from Marion or Possession and Macquarie Islands (distance $\geq 7400 \mathrm{~km}$ ) or among samples from Marion and Possession islands (distance $\sim 1000 \mathrm{~km}$ ) (Table 4).

According to the hierarchical analysis of molecular variance (Table 3 ), the majority of the mtDNA variability of Limnoria stephenseni (65\%) was distributed among islands. In contrast, most genetic variability in Parawaldeckia kidderi (85\%) was attributable to withinisland variation, reflecting the relatively high withinisland polymorphism in this species. All AMOVA results were statistically highly significant [p (random value 
Table 4. Durvillaea antarctica, Limnoria stephenseni and Parawaldeckia kidderi. Pairwise $F_{\mathrm{ST}}$ values between island samples of $D$. antarctica (unshaded), $L$. stephenseni (light-shaded) and P. kidderi (dark-shaded) calculated from nucleotide differences. Significance level of values against 1023 random permutations of sequence samples among islands is given $\left({ }^{*} \mathrm{p}<0.05,{ }^{* *} \mathrm{p}<0.01,{ }^{* * *} \mathrm{p}<\right.$ $0.001, \mathrm{~ns}=$ not significant). The significance $(+)$ and nonsignificance $(-)$ of pairwise differentiation in island samples of $D$. antarctica/L. stephenseni/P. kidderi are summed above diagonal in the lower part of the table; nd = no data

\begin{tabular}{|c|c|c|c|c|c|c|}
\hline & Falkland & Marion & Possession & Kerguelen & Macquarie & Campbell \\
\hline Falkland & & $0.00 \mathrm{~ns}$ & $0.00 \mathrm{~ns}$ & $0.00 \mathrm{~ns}$ & $0.00 \mathrm{~ns}$ & $0.87^{* * *}$ \\
\hline Marion & $0.00 \mathrm{~ns}$ & & $0.00 \mathrm{~ns}$ & $0.00 \mathrm{~ns}$ & $0.00 \mathrm{~ns}$ & $0.86^{* * *}$ \\
\hline Possession & $-0.01 \mathrm{~ns}$ & $0.00 \mathrm{~ns}$ & & $0.00 \mathrm{~ns}$ & $0.00 \mathrm{~ns}$ & $0.84^{* * *}$ \\
\hline Kerguelen & $0.44^{* * *}$ & $0.64^{* * *}$ & $0.61^{* *}$ & & $0.00 \mathrm{~ns}$ & $0.81^{* * *}$ \\
\hline Macquarie & $-0.00 \mathrm{~ns}$ & $0.01 \mathrm{~ns}$ & $-0.01 \mathrm{~ns}$ & $0.51^{* * *}$ & & $0.81^{* * *}$ \\
\hline Campbell & $0.73^{* * *}$ & $0.90^{* * *}$ & $0.88^{* * *}$ & $0.79^{* * *}$ & $0.80^{* * *}$ & \\
\hline Falkland & & $-/-1+$ & $-1-1+$ & $-1+/+$ & $-1-1+$ & $+/+/ \mathrm{nd}$ \\
\hline Marion & $0.19^{* *}$ & & $-/-1-$ & $-1+/-$ & $-1-1-$ & $+/+/$ nd \\
\hline Possession & $0.18^{* *}$ & $-0.01 \mathrm{~ns}$ & & $-1+1-$ & $-1-1-$ & $+/+/$ nd \\
\hline Kerguelen & $0.17^{*}$ & $-0.02 \mathrm{~ns}$ & $0.01 \mathrm{~ns}$ & & $-1+/-$ & $+/+/$ nd \\
\hline Macquarie & $0.21^{* * *}$ & $-0.02 \mathrm{~ns}$ & $0.00 \mathrm{~ns}$ & $-0.01 \mathrm{~ns}$ & & $+/+/$ nd \\
\hline
\end{tabular}

of among-population variation $\geq$ observed value) < 0.0001]. The highly divergent lineages encountered only in the Falkland Islands accounted for all amongisland variability in $P$. kidderi, as shown by the effect of their exclusion from analysis of molecular variance (AMOVA) (Table 3). This finding conforms with the $F_{\mathrm{ST}}$ analysis that found no significant differentiation among island-pairs that did not include Falkland Islands. The high proportion of among-island variability in L. stephenseni was due to the haplotype group exclusive to the Campbell Island sample and to the relatively low frequency of the circumpolar haplotype in the Kerguelen Island as compared to the other populations carrying it.

Fu's $F_{\mathrm{S}}$ statistic gave statistically significant negative values for both the epifaunal species and their host when estimated across all subantarctic samples (Table 3). Parawaldeckia kidderi samples from the Falkland Islands, however, yielded a positive $F_{\mathrm{S}}$ statistic value when analysed separately. Thus, with the exception of $P$. kidderi from the Falkland Islands, mtDNA diversity patterns of the kelp holdfast-dwelling species are consistent with the scenario of historical population expansion.

\section{DISCUSSION}

Our chief finding of circumpolar haplotypes in Durvillaea antarctica and its direct-developing epifaunal invertebrates, across some of the world's largest longitudinal stretches of open ocean, argues in favour of macroalgal rafting in the ACC as an important long- distance dispersal mechanism for intertidal kelp epifauna in the subantarctic. More broadly, macroalgal rafting may be a significant ecological factor explaining similarities in species composition of marine intertidal communities across the subantarctic landmasses affected by the ACC.

\section{Comparison of phylogeographic patterns in southern bull kelp and its epifaunal invertebrates}

The level of mtDNA diversity detected among populations of Parawaldeckia kidderi and Limnoria stephenseni is consistent with each taxon representing a single species across the subantarctic, considering the distribution of COI divergences observed between congeneric crustacean species (Lefébure et al. 2006). Indeed, subantarctic populations of both of these epifaunal invertebrate taxa display high frequencies of a single circumpolar haplotype. Across 5 of the 6 studied islands, the invertebrates also exhibit low phylogenetic diversity that consists of rare haplotypes descended from the common circumpolar haplotype. With the sole exception of Falkland Islands $P$. kidderi, these epifaunal phylogeographic patterns are highly similar to that observed for their macroalgal host (Fraser et al. 2009). An additional concordant pattern detected across taxa is the presence of a distinct Campbell Island haplotype group in both bull kelp and the isopod L. stephenseni (Fig. 3a,c). Finally, all 3 species exhibit genetic signatures of population expansion (neutrality tests), supporting the hypothesis of rapid historical population growth in the circumpolar region.

The strong phylogeographic similarities evident for subantarctic epifaunal species and bull kelp imply that all 3 taxa experienced similar postglacial recolonization histories in at least 5 out of the 6 studied subantarctic islands. Although alternative possible mechanisms exist, e.g. rafting on other substrates (reviewed by Thiel \& Gutow 2005) and anthropogenic introductions, they are relatively unlikely. For instance, Limnoria stephenseni and Parawaldeckia kidderi are not capable of fouling ship hulls, and their successful anthropogenic introduction would likely have required shipping of whole macroalgae with holdfasts. Moreover, Durvillaea antarctica eggs are unlikely to survive more than a few days at sea (Hay 1994), so would be unable to complete ocean crossings in ship ballast; additionally, historic records of bull kelp from the subantarctic islands predate modern ships using 
ballast water (e.g. Choris 1822). On the other hand, as these epifaunal invertebrates are obligate kelpdwellers, macroalgal rafting is clearly the most plausible mechanism to explain their recent circumpolar dispersal. The probability of an individual rafting event following kelp detachment may be low (Miranda \& Thiel 2008), but the apparent abundance of rafts in the subantarctic (Smith 2002) may make such passive dispersal events inevitable over long timescales.

Coalescence theory predicts that populations that have a long uninterrupted history exhibit higher mtDNA nucleotide diversity (further differentiated haplotypes) than populations with short histories (Tajima 1983). Therefore, low genetic diversity and broad genetic similarity of subantarctic bull-kelp populations is thought to reflect postglacial recolonization (Fraser et al. 2009). Although the epifaunal data presented here broadly support postglacial recolonization, the relatively high mtDNA diversity detected in Falkland Islands Parawaldeckia kidderi suggests that these islands may have represented a glacial refuge for this species. The common ancestor of the lineages found at Falkland Islands can be inferred to predate the Last Glacial Maximum unless substitutions in the COI-gene of $P$. kidderi occur at a rate 3 times faster than the fastest short-term COI substitution rate suggested for crustaceans (Audzijonyte \& Väinölä 2006).

For the subantarctic islands whose bull kelp and invertebrate COI variation have both been assessed, the recorded haplotype and nucleotide diversity values are lowest in bull kelp (5 island samples fixed for the circumpolar haplotype), whereas most epifaunal invertebrate samples include a few rare haplotypes (Fig. 3a-c). The singleton kelp COI haplotype FJ550100 reported from Possession (Crozet) Island by Fraser et al. (2009) was found to be an artefact introduced by erroneous base calling, indicating that only the Campbell Island kelp samples exhibit mtDNA diversity. Under neutrality, and assuming that the subantarctic bull kelp and epifaunal populations are of the same postglacial age, this discrepancy in diversity between species might simply be explained by different circumpolar effective population sizes of the taxa. Population genetic theory predicts that, in the absence of selective sweeps, nucleotide diversity $(\pi)$ of a population at mutation-drift equilibrium is the product ( $\pi=4 N_{\mathrm{e}} \mu_{i}$ Tajima 1983) of the mutation rate of DNA $(\mu)$ and the effective population size $\left(N_{\mathrm{e}}\right)$. Alternatively, the discrepancy might reflect variation in COI mutation rate between the species.

\section{Subantarctic biogeography}

Intraspecific genetic diversity of Southern Hemisphere biota remains an understudied topic (Behere- garay 2008), and the subantarctic intertidal zone is particularly poorly studied. Nevertheless, this southern region has distinctive features (sparse intertidal habitat, powerful circumpolar current) that distinguish it from its Northern Hemisphere (Arctic) equivalent, offering a unique setting for studies of long-distance dispersal. In the current study, the genetic similarity of isolated subantarctic populations clearly contrasts with the relatively old geological ages suggested for many of these islands (see Table 1), and apparently conflicts with 'multiregional' models proposed for subantarctic biota (e.g. Greve et al. 2005). On the other hand, the common circumpolar genetic similarity of the bull kelp community supports Udvardy's (1987) hypothesis of a circumpolar 'Insulantarctica' province.

Comparisons with taxa that live in terrestrial habitats - species that are clearly not prone to dispersal by macroalgal rafting - can provide an informative context within which to interpret the findings of the current study. On the one hand, the circumpolar haplotype sharing and low nucleotide diversity of the bull kelp community in most of the studied islands contrasts with the relatively high between-island genetic differentiation and within-island diversity documented for subantarctic populations of weevils (Grobler et al. 2006), springtails (Stevens et al. 2006), and Antarctic hairgrass (van de Wouw et al. 2008). On the other hand, the widespread distribution of a single mitochondrial haplotype in the subantarctic bull kelp and its epifaunal species resembles that of anthropogenically introduced terrestrial species on subantarctic islands (Myburgh et al. 2007). This similarity apparently emphasizes the effectiveness of kelp rafts as dispersal vectors. It appears that natural macroalgal rafting was able to induce an early postglacial genetic homogeneity across the circumpolar region, comparable to human-mediated homogeneity brought about by recent global-scale introductions via ship traffic in other parts of the globe (e.g. Voisin et al. 2005). Also, the contemporary mtDNA haplotype sharing patterns in Limnoria stephenseni and Parawaldeckia kidderi are similar to a ribbon worm, Parborlasia corrugatus, whose long-lived planktonic larvae presumably travel along the ACC between subantarctic islands (Thornhill et al. 2008).

Hypothetically, postglacial recolonization of the subantarctic islands by the bull kelp community could have been mediated by rafting from a single geographical source with subsequent 'stepping-stone' dispersal eastward via the ACC, from one island to the next. Such a history would yield broad genetic homogeneity, as observed here in the form of geographically widespread, numerically dominant mtDNA haplotypes. Specifically, the essentially ubiquitous circumpolar haplotypes observed for each species we looked 
at suggest that their postglacial maternal ancestries can be traced back to single source populations. Although we have sampled most of the known distributional ranges of Limnoria stephenseni and Parawaldeckia kidderi, neither of which occurs in mainland New Zealand, we are presently unable to confidently identify a source region for postglacial recolonization.

Acknowledgements. We are grateful to the persons and organisations that helped us in sample collection, including: I. Ansorge (University of Cape Town) and the South African National Antarctic Program; M. Lebouvier, S. Gutjahr, S. Mallol, J. P. Orts and D. Renault (French Polar Institute, IPEV programme 136); A. Wiebkin, J. Doube and R. Clifton (Australian Antarctic Division); P. Brickle and J. Brown (Department of Fisheries, Falkland Islands) and I. Strange; S. Banks (Department of Conservation, New Zealand) and G. Wilson (University of Otago); Heritage Expeditions. We thank L. J. Cookson and G. Fenwick for taxonomic identifications of isopods and amphipods, respectively. T. King is acknowledged for assistance and advice in the laboratory. K. Miller kindly compiled Fig. 2 from photographs taken by C.I.F. We thank anonymous reviewers for their helpful comments on the manuscript. Resources for our work were provided by the Marsden Fund (contract 07-UOO-099), Shackleton Scholarship Fund, Department of Zoology in the University of Otago and Allan Wilson Centre for Molecular Ecology and Evolution.

\section{LITERATURE CITED}

Audzijonyte A, Väinölä R (2006) Phylogeographic analyses of a circumarctic coastal and a boreal lacustrine mysid crustacean, and evidence of fast post-glacial mtDNA rates. Mol Ecol 15:3287-3301

Beheregaray LB (2008) Twenty years of phylogeography: the state of the field and the challenges for the Southern Hemisphere. Mol Ecol 17:3754-3774

Chin NKM, Brown MT, Heads MJ (1991) The biogeography of Lessoniaceae, with special reference to Macrocystis C. Agardh (Phaeophyta: Laminariales). Hydrobiologia 215: $1-11$

Choris L (1822) Voyage pittoresque autour du monde. Part I. Impr. de Firmin Didot, Paris

> Chown SL, Lee JE, Shaw JD (2008) Conservation of Southern Ocean Islands: invertebrates as exemplars. J Insect Conserv 12:277-291

Clement M, Posada D, Crandall K (2000) TCS: a computer program to estimate gene genealogies. Mol Ecol 9:1657-1660

Cookson LJ (1991) Australasian species of Limnoriidae (Crustacea: Isopoda). Mem Mus Victoria 52:137-262

- Coyer JA, Smith GJ, Andersen RA (2001) Evolution of Macrocystis spp. (Phaeophyceae) as determined by ITS1 and ITS2 sequences. J Phycol 37:574-585

Dartnall AJ (1974) Littoral biogeography. In: Williams WD (ed) Biogeography and ecology in Tasmania. Dr Junk, The Hague, p 171-194

Darwin CR (1845) Journal of researches into the natural history and geology of the countries visited during the voyage of H.M.S. Beagle round the world, under the Command of Capt. Fitz Roy, R.N., 2nd edn. John Murray, London

de Queiroz A (2005) The resurrection of oceanic dispersal in historical biogeography. Trends Ecol Evol 20:68-73

Dhargalkar VK, Verlecar XN (2009) Southern Ocean sea- weeds: a resource for exploration in food and drugs. Aquaculture 287:229-242

Donald KM, Kennedy M, Spencer HG (2005) Cladogenesis as the result of long distance rafting events in South Pacific topshells (Gastropoda, Trochidae). Evolution 59:1701-1711

Ebach MC, Tangney RS (2007) Biogeography in a changing world. CRC Press, Boca Raton, FL

Edgar GJ (1987) Dispersal of faunal and floral propagules associated with drifting Macrocystis pyrifera plants. Mar Biol 95:599-610

Edgar GJ, Burton HR (2000) The biogeography of shallowwater macrofauna at Heard Island. Pap Proc R Soc Tasman 133:23-26

Eltringham SK, Hockley AR (1961) Migration and reproduction of the wood-boring isopod, Limnoria, in Southampton water. Limnol Oceanogr 6:467-482

Excoffier L, Laval G, Schneider S (2005) Arlequin (version 3.0): an integrated software package for population genetics data. Evol Bioinform Online 1:47-50

> Folmer O, Black M, Hoeh W, Lutz R, Vrijenhoek R (1994) DNA primers for amplification of mitochondrial cytochrome c oxidase subunit I from diverse metazoan invertebrates. Mol Mar Biol Biotechnol 3:294-299

Fraser C, Nikula R, Spencer HG, Waters JM (2009) Kelp genes reveal the effects of subantarctic sea ice during Last Glacial Maximum. Proc Natl Acad Sci USA 106: 3249-3253

Fu YX (1997) Statistical tests of neutrality against population growth, hitchhiking and background selection. Genetics 147:915-925

> Garbary D (1987) A critique of traditional approaches to seaweed distribution in light of the development of vicariance biogeography. Helgol Meersunters 41:235-244

Gordillo S (2006) The presence of Tawera gayi (Hupé in Gay, 1854) (Veneridae, Bivalvia) in southern South America: Did Tawera achieve a Late Cenozoic circumpolar traverse? Palaeogeogr Palaeoclimatol Palaeoecol 240:587-601

> Greve M, Gremmen NJM, Gaston KJ, Chown SJ (2005) Nestedness of Southern Ocean island biotas: ecological perspectives on a biogeographical conundrum. J Biogeogr 32: 155-168

Grobler GC, van Rensburg LJ, Bastos ADS, Chimimba CT, Chown SL (2006) Molecular and morphometric assessment of the taxonomic status of Ectemnorhinus weevil species (Coleoptera: Curculionidae, Entiminae) from the subAntarctic Prince Edward Islands. J Zool Syst Evol Res 44: $200-211$

Hay CH (1994) Durvillaea Bory. In: Atsuka I (ed) Biology of economic algae. SPB Academic Publishing, The Hague, p 353-384

Heatwole M, Levins R (1972) Biogeography of the Puerto Rican Bank: flotsam transport of terrestrial animals. Ecology 53:112-117

> Helmuth B, Veit RR, Holberton R (1994) Long-distance dispersal of a subantarctic brooding bivalve (Gaimardia trapesina) by kelp rafting. Mar Biol 120:421-426

$>$ Highsmith RC (1985) Floating and algal rafting as potential dispersal mechanisms in brooding invertebrates. Mar Ecol Prog Ser 25:169-179

Hofmann EE (1985) The large-scale horizontal structure of the Antarctic Circumpolar Current from FGGE drifters. J Geophys Res 90:7087-7097

Humphries CJ, Parenti LR (1999) Cladistic biogeography, 2nd edn. Oxford University Press, New York, NY

Ingolfsson A (1995) Floating clumps of seaweed around Iceland: natural microcosms and a means of dispersal for shore fauna. Mar Biol 122:13-21 
Johannesson K (1988) The paradox of Rockall: Why is a brooding gastropod (Littorina saxatilis) more widespread than one having a planktonic larval dispersal stage $(L$. littorea)? Mar Biol 99:507-513

Lefébure T, Douady CJ, Gouy M, Gibert J (2006) Relationship between morphological taxonomy and molecular divergence within Crustacea: proposal of a molecular threshold to help species delimitation. Mol Phylogenet Evol 40:435-447

Lowry JK, Stoddart HE (1983) The shallow water gammaridean Amphipoda of the subantarctic islands of New Zealand and Australia: Lysianassoidea. J R Soc NZ 13:279-394

Macaya EC, Boltaña S, Hinojosa IA, Macchiavello JE and 6 others (2005) Presence of sporophylls in floating kelp rafts of Macrocystis spp. (Phaeophyceae) along the Chilean Pacific coast. J Phycol 41:913-922

$>$ Miranda L, Thiel M (2008) Active and passive migration in boring isopods Limnoria spp. (Crustacea, Peracarida) from kelp holdfasts. J Sea Res 60:176-183

Morton J, Miller M (1968) The New Zealand sea shore. Collins, Auckland

Muhlin JF, Brawley SF (2009) Recent versus relic: discerning the genetic signature of Fucus vesiculosus (Heterokontophyta; Phaeophyceae) in the northwestern Atlantic. J Phycol 45:828-837

Muhlin JF, Engel CR, Stessel R, Weatherbee RA, Brawley SH (2008) Influence of coastal topography, circulation patterns, and rafting in structuring populations of an intertidal alga. Mol Ecol 17:1198-1210

Myburgh M, Chown SL, Daniels SR, van Vuuren BJ (2007) Population structure, propagule pressure, and conservation biogeography in the sub-Antarctic: lessons from indigenous and invasive springtails. Divers Distrib 13:143-154

Nelson G, Platnick NI (1981) Systematics and biogeography: cladistics and vicariance. Columbia University Press, New York, NY

Ramos-Onsins JE, Rozas J (2002) Statistical properties of new neutrality tests against population growth. Mol Biol Evol 19:2092-2100

Rozas J, Sánchez-Delbarrio JC, Messeguer X, Rozas R (2003) DnaSP, DNA polymorphism analyses by the coalescent and other methods. Bioinformatics 19:2496-2497

Sanmartín I, Wanntorp L, Winkworth RC (2007) West Wind Drift revisited: testing for directional dispersal in the

Editorial responsibility: Hans Heinrich Janssen, Oldendorf/Luhe, Germany
Southern Hemisphere using event-based tree fitting. J Biogeogr 34:398-416

Smith SDA (2002) Kelp rafts in the Southern Ocean. Glob Ecol Biogeogr 11:67-69

Smith SDA, Simpson RD (2002) Spatial variation in the community structure of intertidal habitats at Macquarie Island (sub-Antarctic). Antarct Sci 14:374-384

- Stevens MI, Greenslade P, Hogg ID, Sunnucks P (2006) Southern Hemisphere springtails: Could any have survived glaciation of Antarctica? Mol Biol Evol 23:874-882

> Tajima F (1983) Evolutionary relationship of DNA sequences in finite populations. Genetics 105:437-460

Thiel M, Gutow L (2005) The ecology of rafting in the marine environment. I. The floating substrata. Oceanogr Mar Biol Annu Rev 42:181-264

Thiel M, Haye P (2006) The ecology of rafting in the marine environment. III. Biogeographical and evolutionary consequences. Oceanogr Mar Biol Annu Rev 44:323-428

Thornhill DJ, Mahon AR, Norenburg JL, Halanych KM (2008) Open-ocean barriers to dispersal: a test case with the Antarctic Polar Front and the ribbon worm Parborlasia corrugatus (Nemertea: Lineidae). Mol Ecol 17: $5104-5117$

Udvardy MDF (1987) The biogeographical realm Antarctica: a proposal. J R Soc NZ 17:187-194

van de Wouw M, van Dijk P, Huiskes AHL (2008) Regional genetic diversity patterns in Antarctic hairgrass (Deschampsia antarctica Desv.). J Biogeogr 35:365-376

Voisin M, Engel CR, Viard F (2005) Differential shuffling of native genetic diversity across introduced regions in a brown alga: aquaculture vs. maritime traffic effects. Proc Natl Acad Sci USA 102:5432-5437

Walsh PS, Metzger DA, Higuchi R (1991) Chelex ${ }^{\circledR} 100$ as a medium for simple extraction of DNA for PCR-based typing from forensic material. Biotechniques 10:506-513

> Waters JM (2008) Driven by the West Wind Drift? A synthesis of southern temperate marine biogeography, with new directions for dispersalism. J Biogeogr 35:417-427

Waters JM, Roy MS (2004) Out of Africa: the slow train to Australasia. Syst Biol 53:18-24

Wheeler WM (1916) Ants carried in a floating log from the Brazilian coast to San Sebastian Island. Psyche (Stuttg) 28: 180-183

Submitted: September 29, 2009; Accepted: January 1, 2010 Proofs received from author(s): April 22, 2010 